Article

\title{
Petrogenesis of the Nashwaak Granite, West-Central New Brunswick, Canada: Evidence from Trace Elements, $O$ and Hf Isotopes of Zircon, and $O$ Isotopes of Quartz
}

\author{
Wei Zhang ${ }^{1, *}$, David R. Lentz ${ }^{2}(1)$ and Kathleen G. Thorne ${ }^{3}$ \\ 1 Collaborative Innovation Center for Exploration of Strategic Mineral Resources, School of Earth Resources, \\ China University of Geosciences, Wuhan 430074, China \\ 2 Department of Earth Sciences, University of New Brunswick, Fredericton, NB E3B 5A3, Canada; \\ dlentz@unb.ca \\ 3 Geological Surveys Branch, New Brunswick Department of Energy and Mines, Fredericton, NB E3B 5H1, \\ Canada; kay.thorne@gnb.ca \\ * Correspondence: zhangwei-china@live.cn
}

Received: 4 June 2020; Accepted: 6 July 2020; Published: 9 July 2020

\begin{abstract}
The petrogenesis of the Pridoli to Early Lochkovian granites in the Miramichi Highlands of New Brunswick, Canada, is controversial. This study focuses on the Pridoli Nashwaak Granite (biotite granite and two-mica granite). In situ trace elements and $\mathrm{O}$ and $\mathrm{Hf}$ isotopes in zircon, coupled with $\mathrm{O}$ isotopes in quartz, are used to reveal its magmatic sources and evolution processes. In the biotite granite, inherited zircon cores have broadly homogenous $\delta^{18} \mathrm{O}_{\mathrm{Zrc}}$ ranging from $+6.7 \%$ o to $7.4 \%$ o, whereas magmatic zircon rims have $\delta^{18} \mathrm{O}_{\mathrm{Zrc}}$ of $+6.3 \%$ o to $7.2 \%$ o and $\varepsilon_{\mathrm{Hf}(\mathrm{t})}$ of -0.39 to -5.10 . The $\mathrm{Hf}$ and $\mathrm{Yb} / \mathrm{Gd}$ increase with decreasing Th/U. Quartz is isotopically equilibrated with magmatic zircon rims. The biotite granite is interpreted to be solely derived by partial melting of old basement rocks of Ganderia and fractionally crystallized at the $f \mathrm{O}_{2}$ of $10^{-21}$ to $10^{-10}$ bars. The two-mica granite has heterogeneous inherited zircon cores $\left(\delta^{18} \mathrm{O}_{\mathrm{Zrc}}\right.$ of $+5.2 \%$ o to $9.9 \%$ o) and rims $\left(\delta^{18} \mathrm{O}_{\mathrm{Zrc}}\right.$ of $+6.2 \%$ o to $8.7 \%$ ), and $\varepsilon_{\mathrm{Hf}}(\mathrm{t})$ of -11.7 to -1.01 . The two-mica granite was derived from the same basement, but with supracrustal contamination. This open-system process is also recorded by $\mathrm{Yb} / \mathrm{Gd}$ and $\mathrm{Th} / \mathrm{U}$ ratios in zircon and isotopic disequilibrium between magmatic zircon rims and quartz $(+10.3 \pm 0.2 \%$ ).
\end{abstract}

Keywords: oxygen isotopes; Hf isotopes; zircon; Ganderia; New Brunswick

\section{Introduction}

The Canadian Appalachians formed by accretion of several Gondwanan microcontinents to Laurentia as a result of Early to Late Paleozoic closure of the Iapetus and Rheic oceans [1]. Three phases of orogenesis recorded by various rock suites in New Brunswick are known as Taconic, Salinic, and Acadian orogenesis. The Taconic orogeny was manifested by accretion of three oceanic and continental terranes in the peri-Laurentia realm (500-450 Ma). Closure of the Tetagouche-Exploits backarc basin along the Bamford Brook Fault in Ganderia resulted from the Salinic orogeny (450-423 Ma). This was then followed by the Acadian orogeny due to the northwest flat-slab subduction of Avalonia beneath Ganderia along the Caledonia Fault (421-400 Ma) [2]. New Brunswick is mostly underlain by Neoproterozoic Ganderian basement (sedimentary rocks and arc volcanic rocks) that is overlain by Cambro-Ordovician, quartz-rich, passive margin sedimentary rocks. Ganderia is bordered to the north by arc volcanic rocks of the peri-Laurentian Notre Dame zone, and by the Avalonian microcontinent along the Caledonian Fault to the south [3]. Although both Ganderia and Avalonia are 
peri-Gondwanan microcontinents, they have contrasting crustal compositions. Compared to Avalonia's "juvenile" Neoproterozoic crust (crustal source material with a short residence time) and ubiquitous $\delta^{18} \mathrm{O}$-depletion of the Neoproterozoic sedimentary rocks, Ganderia has "old" Neoproterozoic basement with high- $\delta^{18} \mathrm{O}$ sedimentary cover $[4,5]$.

Voluminous Pridoli to Early Lochkovian granites occur in the Miramichi Highlands of Ganderia (Figure 1). Previous whole-rock Sr, $\mathrm{Nd}$, and $\mathrm{O}$ isotope studies invoke contributions from mantle, infracrustal, and supracrustal sources in both New Brunswick and Newfoundland [3,4,6]. These granites could be associated with (a) crustal delamination after closure of the Tetagouche-Exploits backarc basin (450-424 Ma, [7]) along the Bamford Brook Fault (Salinic orogeny, [3,6]); (b) flat-slab subduction of Avalonia beneath Ganderia preceding the Acadian orogeny (423-400 Ma, [2]); or (c) other processes, such as break-off of Tetagouche-Exploits back-arc crust following the collision of Ganderia with composite Laurentia in the Late Silurian [8]. Controversy about petrogenesis of these granites needs to be clarified (e.g., $[3,9,10])$.

Zircon, as a refractory mineral, can potentially preserve oxygen and hafnium isotope compositions of its source as well as host magma [11-13]. Furthermore, oxygen isotopes from quartz and zircon as well as zircon trace elements are effective tools to record assimilation and fractional crystallization (AFC) processes [14-17]. Therefore, in this study we carried out in situ analysis of trace elements, Hf and oxygen isotopes of zircon, and oxygen isotopes of quartz in order to better decipher the magmatic sources of the Nashwaak Granite, as well as the physicochemical conditions during magmatic evolution, and to discuss the possible mechanism that generated the Nashwaak Granite.
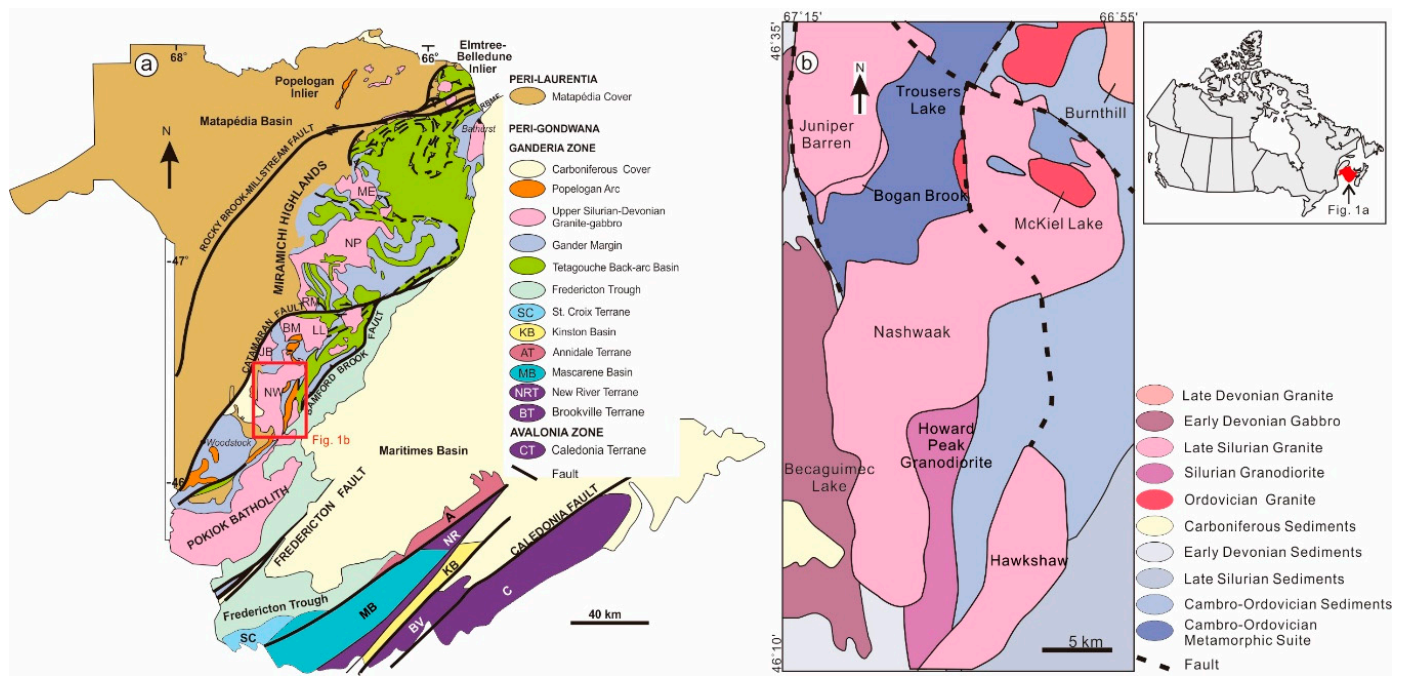

Figure 1. (a) Lithotectonic terranes of New Brunswick and (b) regional geological map, showing the distribution of the Nashwaak Granite (after [8]). Abbreviations of terranes: A-Annidale terrane; BV-Brookville terrane; $\mathrm{C}$-Caledonia terrane; KB-Kingston basin; MB-Mascarene basin; NR-New River terrane; SC-St.Croix terrane. Abbreviations of granites: BM-Beadle Mountain Granite; JB-Juniper Barren Granite; LL_Lost Lake Granodiorite; ME-Mount Elizabeth Granite; NP—North Pole Granite; NW-Nashwaak Granitic Suite.

\section{Geological Background}

The Nashwaak Granite intruded the Cambro-Ordovician Trousers Lake Metamorphic Suite and the Ordovician McKiel Lake Granite to the north, and the Becaguimec Lake Gabbro to the west. The contact between the Nashwaak Granite and Early Devonian volcanic rocks to the south is not exposed. On its east side, the Nashwaak Granite intruded quartzose wackes, siltstones, and shales of the Cambrian-Early Ordovician Miramichi Group, and younger volcanic and sedimentary rocks of the Ordovician Tetagouche Group (Figure 1). Andalusite and cordierite are present in sedimentary rocks up to $2 \mathrm{~km}$ from the contact. 
The Nashwaak Granite has two subfacies: (1) pink, coarse- to medium-grained, equigranular to porphyritic biotite granite with a mineral assemblage of plagioclase, orthoclase, quartz, and minor biotite, grading northward into (2) fine- to medium-grained muscovite-biotite granite containing quartz, microcline, albite, muscovite, zircon, apatite, monazite, and ilmenite. The Nashwaak Granite was formed at ca. $420 \mathrm{Ma}$ and is highly siliceous (69.3-81.5 wt.\%), calc-alkaline, and peraluminous, with $(\mathrm{La} / \mathrm{Yb})_{\mathrm{N}}$ ranging from 1.9 to 13.6 , and depletion of $\mathrm{Ba}, \mathrm{Sr}, \mathrm{Nb}, \mathrm{P}$, and Ti. The $\varepsilon_{\mathrm{Nd}}(t)$ is from -2.1 to $-4.2[8]$.

\section{Analytical Methods}

In this study, we used the same [8] zircon samples from the Nashwaak Granite as we previously dated for their $\mathrm{U}-\mathrm{Pb}$ ages. Some of the zircons show inherited cores with ${ }^{206} \mathrm{~Pb} /{ }^{238} \mathrm{U}$ ages ranging from 1000 to $1945 \mathrm{Ma}$ and ${ }^{207} \mathrm{~Pb} / 206 \mathrm{~Pb}$ ages of 1040 to $2260 \mathrm{Ma}$ [8]. With guidance from cathodoluminescence (CL) images, zircon grains with overgrowth magmatic rims (identified by similar ${ }^{206} \mathrm{~Pb} /{ }^{238} \mathrm{U}$ age as that sample's concordia age) were selected for in situ trace element analysis at the rims. Oxygen isotope analysis was conducted on both rims and inherited cores. Only the zircon rims used for the concordia age calculation were chosen for hafnium isotope analysis. Detailed analytical methods are listed below.

\subsection{Oxygen Isotope Analysis of Zircon and Quartz}

Secondary ion mass spectrometry (SIMS) oxygen isotope analysis of zircon and quartz was carried out using a Cameca IMS 1280 ion microprobe (manufactured by CAMECA, Société par Actions Simplifiée, Gennevilliers, France) at the Canadian Centre for Isotopic Microanalysis (CCIM), University of Alberta. $\mathrm{A}^{133} \mathrm{Cs}^{+}$primary beam was operated with an impact energy of $20 \mathrm{keV}$ and a $2-4 \mathrm{nA}$ beam current. The $\sim 12 \mu \mathrm{m}$ diameter probe was rastered slightly during acquisition to form rectangular sputtered areas of $\sim 15 \mu \mathrm{m} \times 18 \mu \mathrm{m}$. Negative secondary ions were extracted from the sputtered area into the secondary (transfer) column by application of a $10 \mathrm{kV}$ potential gradient. Transfer conditions included a $122 \mu \mathrm{m}$ entrance slit, a $400 \mu \mathrm{m}$ contrast aperture, and a $5 \mathrm{~mm}$ field aperture. The energy window utilized was $150 \mathrm{eV}$. The mass-separated oxygen isotopes were detected simultaneously in Faraday cups $\mathrm{L}^{\prime} 2\left({ }^{16} \mathrm{O}^{-}\right)$and $\mathrm{H}^{\prime} 2\left({ }^{18} \mathrm{O}^{-}\right)$in the multidetector array. Mass resolution $(\Delta \mathrm{m} / \mathrm{M}$ at $10 \%)$ was typically 1950 and 2275, respectively (see [18]). For quartz, reference material S0033 was used (GeeWiz glass [19]); the measured $\delta^{18} \mathrm{O}$ value of $+12.34 \pm 0.05 \%$ o $(n=12)$ agrees well with the reported value of $+12.5 \%$ o. Median uncertainties for the quartz reference materials and samples at $95 \%$ confidence $(2 \sigma)$ were $\pm 0.17 \%$ o (Table S1). For zircon, an internal reference material S0081 (UAMT1) was used; the measured $\delta^{18} \mathrm{O}_{\mathrm{VSMOW}}$ value of $+4.81 \pm 0.04 \%$ o agrees well with the accepted value of $+4.87 \%$ o (Stern R., unpublished data). At $95 \%$ confidence, the median uncertainty for the zircon reference materials and samples is \pm 0.19 and $\pm 0.18 \%$ o, respectively (Table S2).

\subsection{Trace Element and Hf Isotopic Analysis of Zircon}

The in situ zircon trace element analyses were conducted using a Resonetics M-50-LR $193 \mathrm{~nm}$ (manufactured by Resonetics at Kettering, OH, USA) Excimer laser ablation system coupled to an Agilent 7700× quadrupole inductively coupled plasma-mass spectrometer (ICP-MS) (manufactured by Agilent technologies at Santa Clara, CA, USA) at the University of New Brunswick. A spot size of $33 \mu \mathrm{m}$, a beam energy of $4 \mathrm{~J} / \mathrm{cm}^{2}$, and an $8 \mathrm{~Hz}$ laser repetition rate were employed. Calibration was achieved using standard procedures [20] that included use of standard reference materials (SRM) 610 glass from National Institute of Standards and Technology (NIST) for external standardization and the stoichiometric $\mathrm{SiO}_{2}$ content of zircon for internal standardization (Table S3).

To evaluate whether the laser ablation spot was placed on a mineral inclusion (i.e., monazite, apatite, and titanite) that was not detectable at the scale of optical and CL imaging, the spots with extremely high content of $\mathrm{Ca}, \mathrm{Sr}$, Th, and $\mathrm{P}$ were carefully checked. Results with strong correlation between $\mathrm{P}$ and $(\mathrm{Sm} / \mathrm{La})_{\mathrm{N}}$, Th and $(\mathrm{Sm} / \mathrm{La})_{\mathrm{N}}$, or $\mathrm{Ca} / \mathrm{Sr}$ and light rare earth elements (LREE), indicating the presence of monazite or apatite, were discarded (see [21]). 
In situ Hf isotope analyses of zircons were conducted using a Resolution S-155 laser-ablation system with a beam size of $50 \mu \mathrm{m}$ and a pulse frequency of $8 \mathrm{~Hz}$, coupled with a Nu Plasma II multicollector ICP-MS at the State Key Laboratory of Geological Processes and Mineral Resources, China University of Geosciences (GPMR), Wuhan. The reference standard Penglai zircon with a ${ }^{176} \mathrm{Hf} /{ }^{177} \mathrm{Hf}$ ratio of $0.282906 \pm 0.000001(2 \sigma)$ was analyzed along with the samples [22]. Detailed information about the analytical method can be found in [23] (Table S4).

\section{Results}

\subsection{Trace Elements in Zircon}

Zircon rims in the two-mica granite show contents of Th and $U$ in the range of 42 to $476 \mathrm{ppm}$ and of 88 to 2260 ppm, respectively, with Th/U ratios of 0.02 to 0.91 (Figure 2a). Contents of $\mathrm{Zr}$ and $\mathrm{Hf}$ vary from 40.3 to $43.6 \mathrm{wt}$ \% $\%$ and 7680 to $19,080 \mathrm{ppm}$, respectively. The Eu/Eu* and $\left(\mathrm{Ce} / \mathrm{Ce}^{*}\right)_{\mathrm{D}}$ values calculated using the lattice-strain model of [24] are 0.08 to 1.74 and 2.65 to 25.3, respectively (Figure 2b,c; Table S3). $\mathrm{Yb} / \mathrm{Gd}$ ratios in them are in the range of 9.44 to 62.0 (Figure $2 \mathrm{~d}$ ). The total REE contents range from 250 to $2487 \mathrm{ppm}$ and the chondrite-normalized REE patterns show a strong enrichment of heavy rare earth elements (HREE) (Figure 3a).
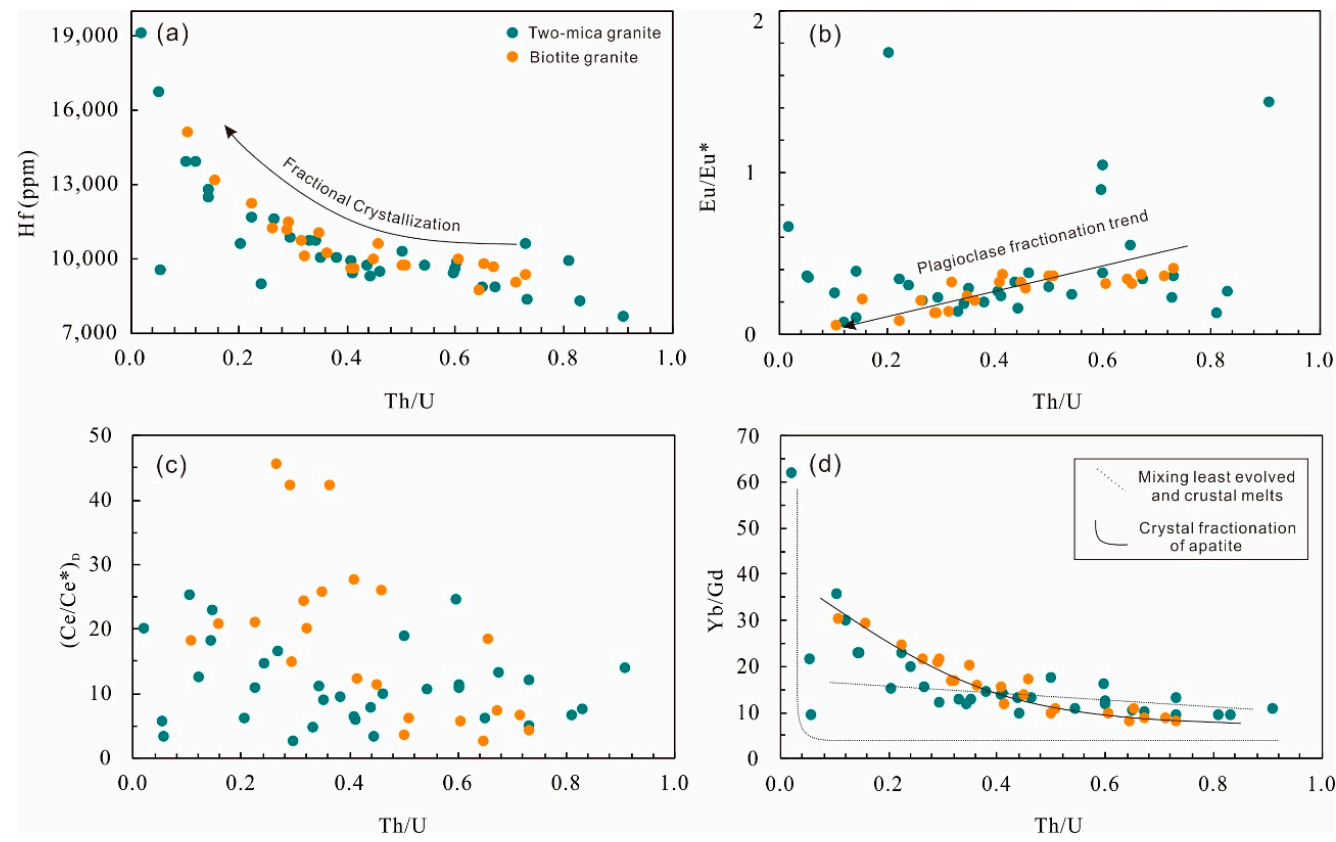

Figure 2. Hafnium (a), $\mathrm{Eu} / \mathrm{Eu}^{*}(\mathbf{b}),\left(\mathrm{Ce} / \mathrm{Ce}^{*}\right)_{\mathrm{D}}(\mathbf{c})$ and $\mathrm{Yb} / \mathrm{Gd}(\mathbf{d})$ vs. Th/U of zircons from the Nashwaak Granite.
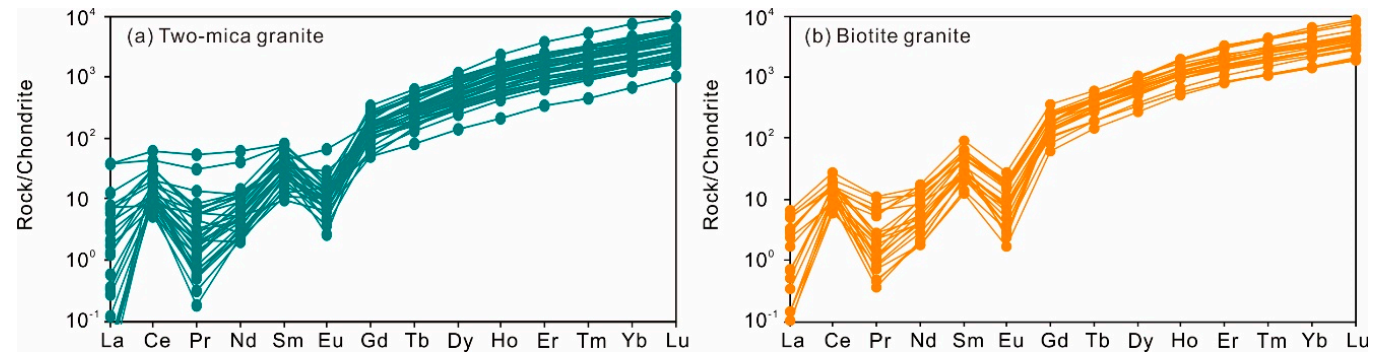

Figure 3. Chondrite-normalized [25] rare earth elements of zircons from the two-mica granite (a) and biotite granite (b). 
The zircon rims from biotite granite show similar Th (52-363 ppm) and U (126-2480 ppm) contents and $\mathrm{Th} / \mathrm{U}$ ratios $(0.11-0.73)$ to the two-mica granite zircons (Figure $2 \mathrm{a}$ ). Their calculated Eu/Eu* values of 0.06 to 0.41 and $\left(\mathrm{Ce} / \mathrm{Ce}^{*}\right)_{\mathrm{D}}$ values of 2.48 to 45.6 (Figure $2 \mathrm{~b}, \mathrm{c}$; Table S3) are based on the method of [24]. They also have similar Zr (39.9-43.5 wt.\%) and Hf (8750-15,090 ppm) contents. The total REE content in them ranges from 539 to 2130 ppm (Figure 3b).

\subsection{Images and Oxygen Isotopes in Zircon and Quartz}

The quartz grains in the biotite granite and two-mica granite are green and bluish red in ChromaSEM-CL (Figure 4). They are dominantly homogeneous and composed of only one generation of primary igneous quartz. A few quartz grains show oscillatory zoning at $\mu \mathrm{m}$ scale, revealed by small-amplitude variations in CL (Figure 4d). Secondary textures in the magmatic quartz from the Nashwaak Granite include: (1) dark CL streaks and patches associated with fractures; (2) healed fractures, which do not show up in BSE images, and are likely filled by nonluminescent $\mathrm{SiO}_{2}$ (see [26]); and (3) opened fractures.
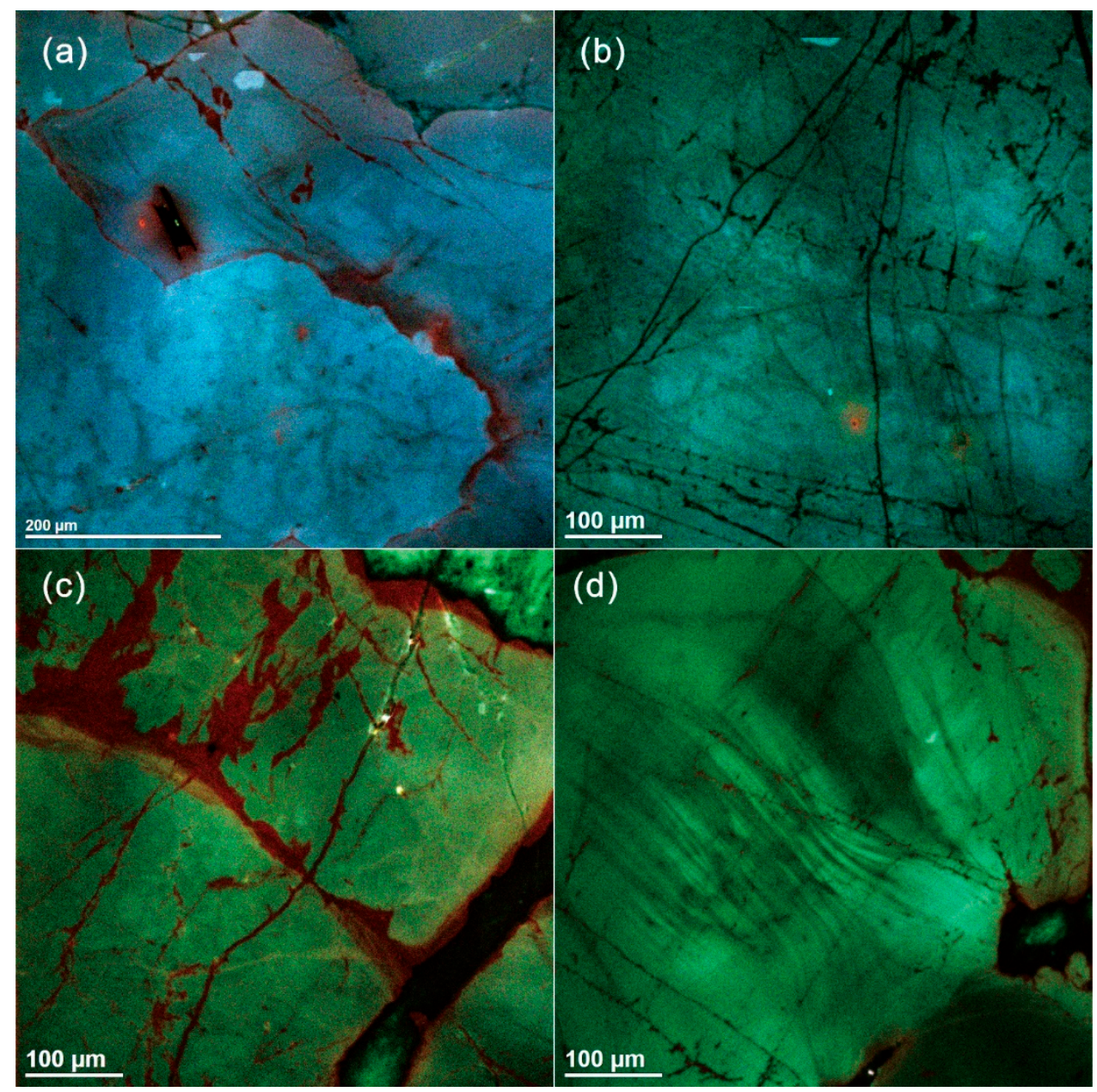

Figure 4. Scanning electron microscope-cathodoluminescence (SEM-CL) images of quartz from the Nashwaak Granite. In the two-mica granite, (a) visible oscillatory zoning parallel to grain boundary and (b) homogeneous quartz with fractures. In the biotite granite, (c) homogenous quartz with fluids infiltration along fractures and (d) oscillatory zoning.

Overall, $\delta^{18} \mathrm{O}$ of quartz shows limited or no intragranular variations in each granite sample. In the two-mica granite, the mean $\delta^{18} \mathrm{O}_{\mathrm{Qz}}$ is $+10.3 \pm 0.2 \%$ o $(2 \sigma, n=11)$, which is slightly higher than that of 
the biotite granite with a mean of $+9.7 \pm 0.2 \%$ o $(2 \sigma, n=19)$. Detailed examination of magmatic quartz yielded consistent $\delta^{18} \mathrm{O}_{\mathrm{Qz}}$ values, regardless of distance from the rim of a grain (Table S1).

Two zircon populations were identified using SEM-CL: (1) prevalent high-CL response (bright) zircon domains (cores or whole crystals); and (2) thin, low-CL response rims (Figure 5). Attempts were made to analyze both of these domains; however, due to the small size of the zircon crystals and the internal fracturing observed in many grains, it was not always possible to fit multiple analyses on a single crystal. Intragrain $\delta^{18} \mathrm{O}_{\mathrm{Zrc}}$ values from the two-mica granite are highly variable; ranging from $+5.2 \%$ o to $9.9 \%$ o (mean $+7.4 \%$ o) for the bright cores, and $+6.2 \%$ o to $8.7 \%$ o (mean $+7.1 \%$ o) for the overgrowth oscillatory rims (Figure $6 \mathrm{a}, \mathrm{b}$ ). The $\delta^{18} \mathrm{O}_{\mathrm{Zrc}}$ values either increase or decrease from core to rim, with a range of $0.3 \%$ o to $2.5 \%$. Considering that analytical uncertainties are generally $< \pm 0.2 \%$ o $(2 \sigma)$, these intergrain and intragrain variations likely represent real oxygen isotopic heterogeneity. In contrast, zircon from the biotite granite shows generally lower $\delta^{18} \mathrm{O}_{\mathrm{Zrc}}$ values and limited variation between cores $(+6.7-7.4 \%$; mean $=+7.0 \%$ o $)$ and rims $(+6.3 \%$ ond $7.2 \%$; mean $=+6.8 \%$ o $)($ Figure $6 \mathrm{c}, \mathrm{d}$; Table S2). The core-rim variation of each grain is insignificant within a range of less than $0.4 \%$ o.

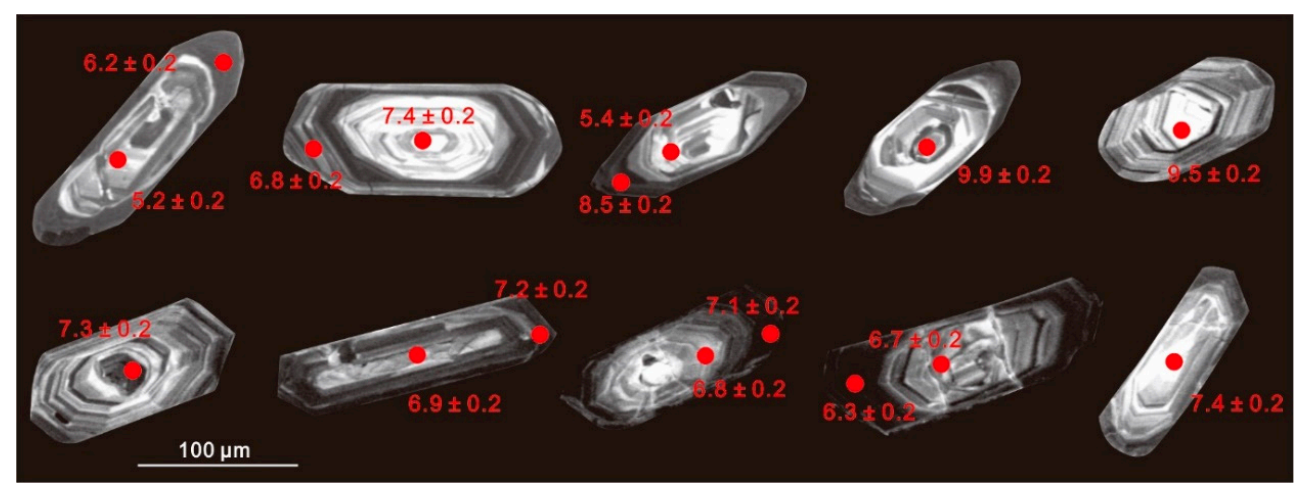

Figure 5. Cathodoluminescence (CL) images of representative zircons from the two-mica granite (first row) and the biotite granite (second row). Circles indicate the location of ion microprobe analysis spots, $\delta^{18} \mathrm{O}$ values are beside each circle.
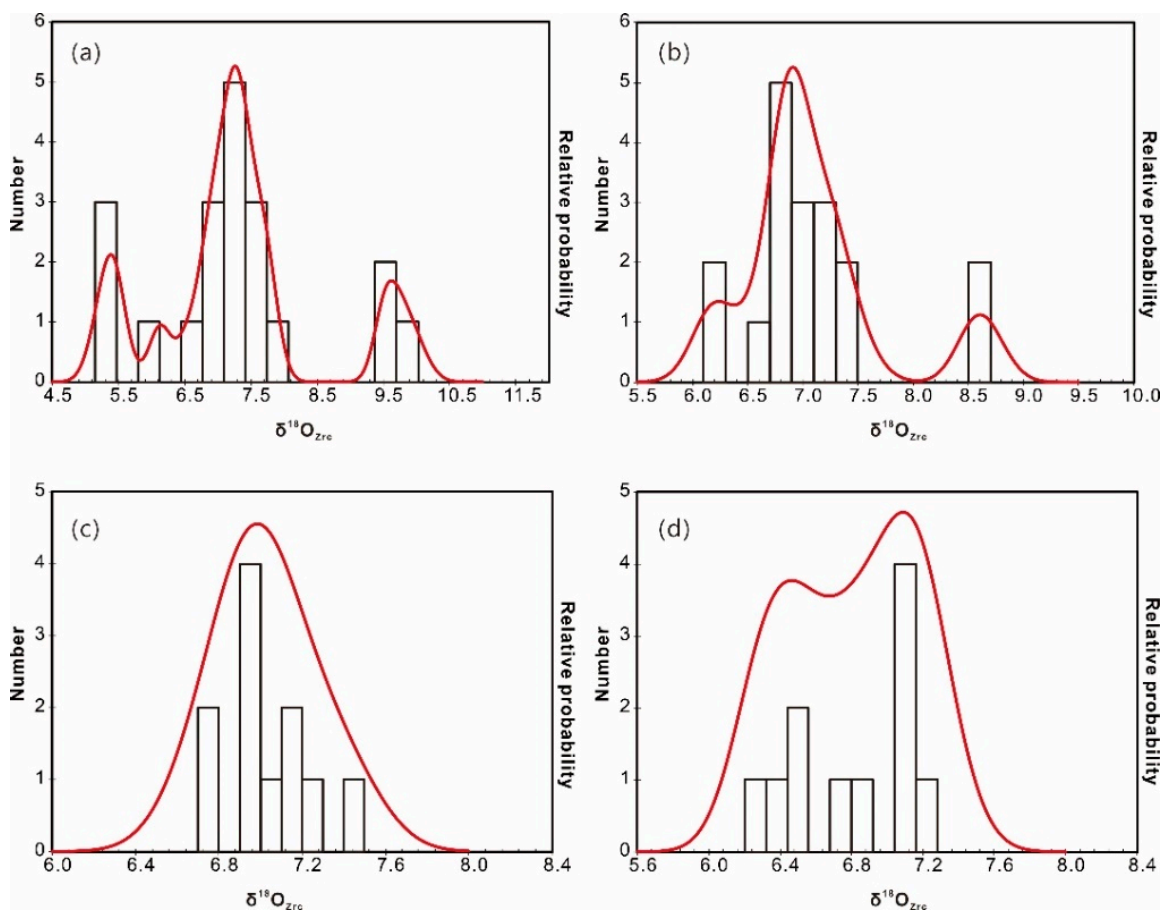

Figure 6. Cumulative probability histograms of $\delta^{18} \mathrm{O}_{\mathrm{Zrc}}$ of the zircon cores (a) and rims (b) from the two-mica granite, and zircon cores (c) and rims (d) from the biotite granite. 


\subsection{Hafnium Isotopes in Zircon}

Zircons in the two-mica granite show a large range of ${ }^{176} \mathrm{Hf} /{ }^{177} \mathrm{Hf}$, from 0.28219 to 0.28250 , corresponding to $\varepsilon_{\mathrm{Hf}(\mathrm{t})}$ values ranging from -11.7 to -1.0, with two-stage $\mathrm{Hf}$ model ages from 1464 to $2135 \mathrm{Ma}$. In contrast, zircons from the biotite granite show less variation in ${ }^{176} \mathrm{Hf} /{ }^{177} \mathrm{Hf}$ ratios $(0.28238$ to 0.28251 ) and $\varepsilon_{\mathrm{Hf}(\mathrm{t})}$ values (from -0.4 to -5.1 ), with more limited two-stage Hf model ages from 1427 to 1724 Ma (Figure 7; Table S4).

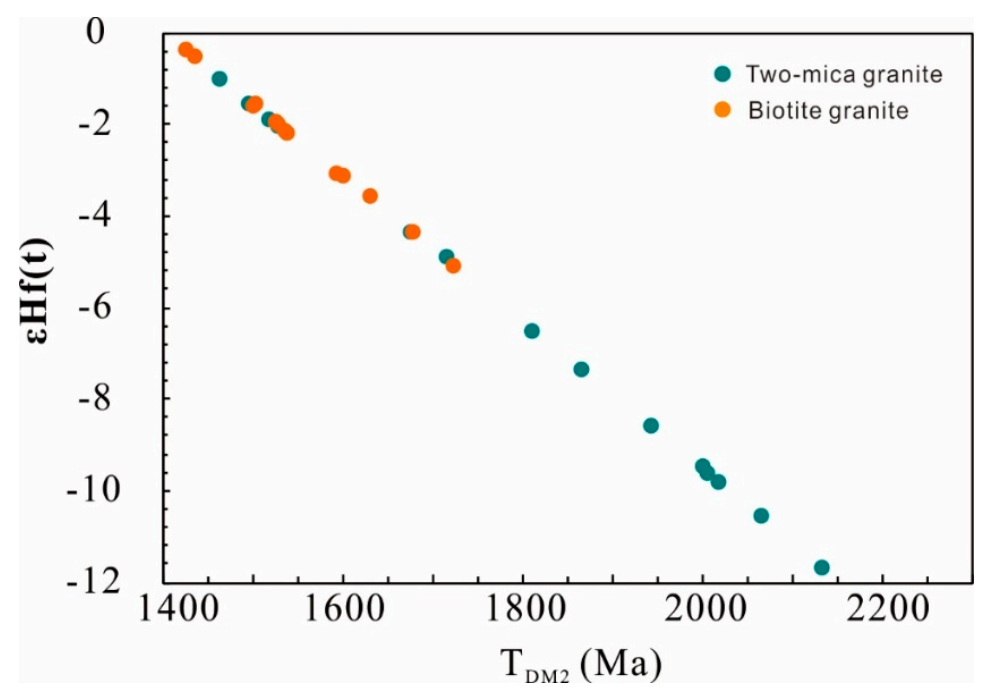

Figure 7. $\mathrm{T}_{\mathrm{DM} 2}$ vs. $\varepsilon_{\mathrm{Hf}}(t)$ of zircons from the Nashwaak Granite.

\section{Discussion}

\subsection{Crystal Fractionation and Contamination}

Trace elements incorporated into zircon reflect the composition of host magma in which it is growing. Crystal fractionation produces residual melts with relatively higher $U$ and Th content; consequently zircon in such melts evolves toward high Th and U content and low Th/U [27]. Hafnium increases and $\mathrm{Zr} / \mathrm{Hf}$ decreases in zircon with magma cooling [28-30]. Both the biotite granite and two-mica granite in the Nashwaak Granite have similar U and Th content (Table S3), but zircon rims in the two-mica granite have a wider range of Th/U and Hf content. Relative enrichment in HREE over middle rare earth elements (MREE) in zircons is interpreted as a result of mineral (garnet, hornblende, titanite, and apatite) fractionation in a closed system (Table S3, [17]). In the Nashwaak Granite, only apatite typically occurs as inclusions within biotite. The plot of $\mathrm{Th} / \mathrm{U}$ versus $\mathrm{Yb} / \mathrm{Gd}$ may differentiate crystal fractionation and mixing/contamination ([17], Figure 2d). For example, zircon rims of the biotite granite follow the crystal fractionation curve, whereas zircon rims of the two-mica granite are distributed along a mixing curve where Th/U is higher than 0.2 (Table S3). When Th/U is lower than 0.2, zircon rims of two-mica granite plot on the crystal fractionation trend, but some of these grains have relatively high Ti contents (corresponding to high temperatures; [31]), which contradicts a gradual cooling process during fractional crystallization. Thus, zircons with low Th/U and high Ti may also be formed by crustal contamination.

\subsection{Titanium-In-Zircon Thermometry}

The titanium-in-zircon thermometer [28,31,32] provides zircon crystallization temperatures in host melts [17]. Two key parameters of this thermometer are the activities of $\mathrm{SiO}_{2}\left(a \mathrm{SiO}_{2}\right)$ and $\mathrm{TiO}_{2}$ $\left(a \mathrm{TiO}_{2}\right)$ in the magma. Model temperatures are calculated for magmas with titanite, in which case a value of 0.7 is adopted for $a \mathrm{TiO}_{2}$, as suggested by [17] and [33]. Variation of 0.1 in $a \mathrm{TiO}_{2}$ leads to changes of 25 to $30{ }^{\circ} \mathrm{C}$ in the calculated temperatures. For the Nashwaak Granite, the $a \mathrm{SiO}_{2}$ is 1.0 due 
to the presence of quartz, and $a \mathrm{TiO}_{2}$ is 0.6 , based on the absence of titanite ( 0.6 is the minimum for felsic magmas). According to this model, the Ti contents of magmatic rims from the biotite granite broadly crystallized at 710 to $850{ }^{\circ} \mathrm{C}$, whereas those of the two-mica granite mainly crystallized between 750 and $800{ }^{\circ} \mathrm{C}$ (Figure 8; Table S3).
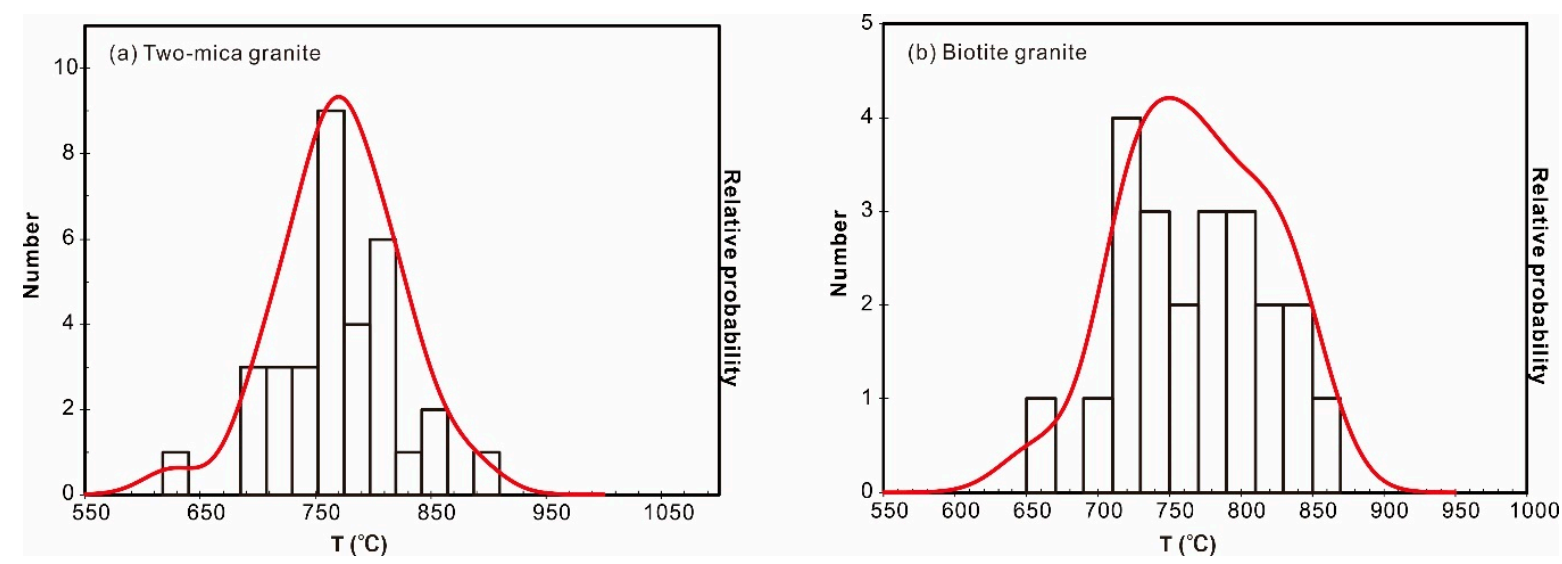

Figure 8. Cumulative probability histograms of the Ti-in-zircon thermometer [31] for the two-mica granite (a) and biotite granite (b).

\subsection{Oxygen Fugacity}

Variation of $\mathrm{Ce}$ and Eu anomalies in zircon (Figure 2) reflects the oxidation state of magmas [17]. Cerium and $\mathrm{Eu}$ have two valence states. Compared with $\mathrm{Ce}^{3+}, \mathrm{Ce}^{4+}$ is incorporated preferentially into the $\mathrm{Zr}^{4+}$ site of zircon; whereas $\mathrm{Eu}^{2+}$ is easily accommodated into the $\mathrm{Ca}^{2+}$ site of plagioclase. An increase in the oxidation state of magma enhances the positive Ce anomaly, but weakens the negative Eu anomaly in zircon [34].

The Eu/Eu* of zircon rims in the biotite granite generally decreases along with increasing Hf content and decreasing Th/U (Figure 2). Although the influence of oxygen fugacity cannot be totally precluded, the enhancement of a negative Eu anomaly might be dominantly controlled by plagioclase fractional crystallization [30]. Zircon rims in the two-mica granite generally have a Eu/Eu* broadly lower than 0.4 , but some scattered values are in the range of 0.6 to 1.8 (Figure $2 \mathrm{~b}$ ). In this case, crustal contamination as discussed above may play a vital role in evolution of the two-mica granite.

An alternative method to evaluate the oxidation state of magma uses the zircon Ce anomaly. In order to avoid error in the estimation of $\mathrm{Ce} / \mathrm{Ce}^{*}$ arising from low $\mathrm{La}$ and Pr content in zircon, the lattice-strain model [24] was used to calculate $\mathrm{Ce} / \mathrm{Ce}^{*}$, corresponding $\mathrm{Ce}^{4+} / \mathrm{Ce}^{3+}[35]$, and oxygen fugacity [36] of the magmas. The zircon rims from the biotite granite have $\mathrm{Ce}^{4+} / \mathrm{Ce}^{3+}$ in the range of 1.5 to 44.6 (mean 17.5), with calculated $f \mathrm{O}_{2}$ of $10^{-21}$ to $10^{-10}$ (mean $10^{-15}$ bars) (Figure 9), whereas the zircon rims from the two-mica granite are relatively reduced with $\mathrm{Ce}^{4+} / \mathrm{Ce}^{3+}$ of 1.7 to 24.4 (mean 10.1) and calculated $\mathrm{fO}_{2}$ of $10^{-23}$ to $10^{-13}$ (mean $10^{-17}$ ) bars (Figure 9; Table S3). An evolution of $f \mathrm{O}_{2}$ with progressive crystallization in two-mica granite is not observed, whereas the $f \mathrm{O}_{2}$ of biotite granite increases with decreasing $\mathrm{Th} / \mathrm{U}$. This oxidation state could be attributed to $\mathrm{H}_{2}$ degassing [37] or the result of reduction of sulfate to sulfur dioxide during separation of a sulfur-rich magmatic-hydrothermal fluid [38]. 


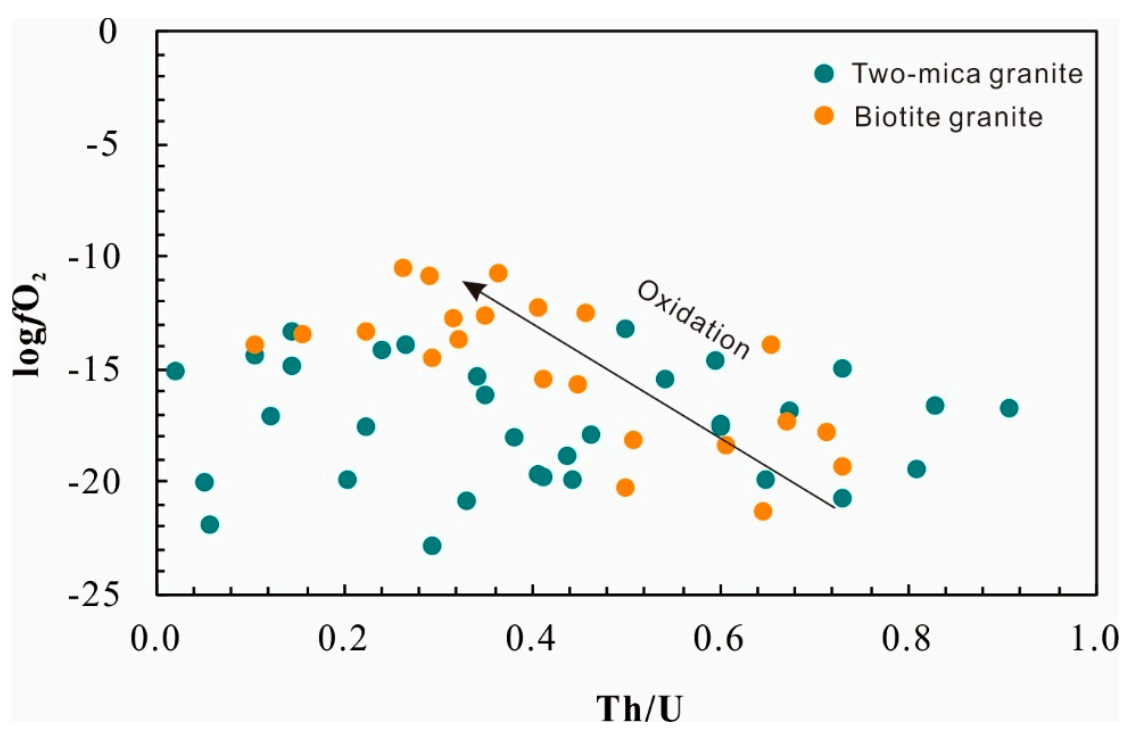

Figure 9. Oxygen fugacity variation during magma evolution $(\mathrm{Th} / \mathrm{U})$ reflected by the composition of zircon from the Nashwaak Granite.

\subsection{Magma Sources and Evolution as Recorded by O-Hf Isotopes}

Oxygen isotope fractionation between zircon and quartz is a function of temperature and is independent of oxygen fugacity or pressure (Equation (1)):

$$
\delta^{18} \mathrm{O}_{\mathrm{Qtz}}-\delta^{18} \mathrm{O}_{\mathrm{Zrc}}=\Delta_{\mathrm{Qtz}-Z \mathrm{Zrc}} \approx 1000 \ln \left(\alpha_{\mathrm{Qtz}-Z \mathrm{rc}}\right)=\mathrm{A}_{\mathrm{Qtz}-\mathrm{Zrc}} 10^{6} / \mathrm{T}^{2}
$$

where $A_{Q t z-Z r c}=2.33 \pm 2.04$ [39] or 2.64 [40] and $T=$ temperature in Kelvin.

If quartz and zircon are in isotopic equilibrium at a particular temperature, then their $\delta^{18} \mathrm{O}$ values should lie along a straight line in a plot of $\delta^{18} \mathrm{O}_{\mathrm{Zrc}}$ vs. $\delta^{18} \mathrm{O}_{\mathrm{Qtz}}$ (see Figure $5 \mathrm{~b}$ in [11]). In the biotite granite, the $\delta^{18} \mathrm{O}_{\mathrm{Zrc}}$ value of the magmatic rim is broadly homogenous (from $+6.3 \%$ o to $+7.2 \%$ o). Consequently, the zircon and quartz in the biotite granite might have formed in a closed system and equilibrated with their hosting magma during crystallization. The average $\delta^{18} \mathrm{O}$ values of zircon rims and quartz are $+6.8 \%$ o and $+9.7 \%$, respectively. The value of $\Delta_{\mathrm{Qtz}-Z \mathrm{rc}}$ is $2.9 \%$ o and the calculated temperature is $688^{\circ} \mathrm{C}$ (Tables S1 and S2; [40]) or $675^{\circ} \mathrm{C}$ [39].

In the two-mica granite, the zircon has heterogeneous cores with the $\delta^{18} \mathrm{O}_{\mathrm{Zrc}}$ ranging from $+5.2 \%$ to $+9.9 \%$, indicating various magmatic sources. The zircon rims have $\delta^{18} \mathrm{O}_{\mathrm{Zrc}}$ in the range of $6.2 \%$ o to $8.7 \%$ o with a mean value of $7.1 \%$. The average O-isotope fractionation between zircon rims and quartz yields an equilibration temperature below $640{ }^{\circ} \mathrm{C}$ [40] or $627^{\circ} \mathrm{C}$ [39], much lower than the Ti-in-zircon temperatures. Furthermore, the $2.5 \%$ o difference of $\delta^{18} \mathrm{O}_{\mathrm{Zrc}}$ in the zircon rims indicates that this magma crystallized in an open system.

Oxygen isotope disequilibrium between zircon and quartz could be caused by several processes, as suggested by [16] for granitoids elsewhere. Feldspar and quartz are less refractory minerals in granites compared to zircon, therefore their oxygen isotope compositions could be readily reset by hydrothermal alteration and recrystallization $[15,41,42]$. However, large-scale or intense hydrothermal alteration is not evident in the Nashwaak Granite, as indicated by the quartz texture in the CL images. Although quartz grains in biotite granite rarely have dilatant fractures along which hydrothermal alteration could occur (Figure 4c), transects across whole magmatic quartz grains do not show any $\delta^{18} \mathrm{O}_{\mathrm{Qz}}$ variation, suggesting that hydrothermal alteration was not a main process causing oxygen isotope disequilibrium between quartz and zircon.

Magma mixing (e.g., [43-45]), and crustal assimilation (e.g., [14-16,46,47]) are other processes that can change the $\delta^{18} \mathrm{O}$ composition of melts. As shown in [48], early-crystallizing zircon has lower $\delta^{18} \mathrm{O}$ than late-crystallized garnet, which formed after contamination of the granitic magma by assimilation 
of sedimentary rocks. Supracrustal contamination in the two-mica granite is indicated by the presence of high $\delta^{18} \mathrm{O}(>+8 \%$ o) zircon cores. Such a contamination process could affect the composition and oxygen fugacity of melts. That the $\delta^{18} \mathrm{O}$ of magmatic quartz in the two-mica granite did not record the input of supracrustal materials might be due to very late stage crystallization of quartz, after the magma was completely homogenized (see [43]).

Various magma sources can be identified by the oxygen isotope compositions of zircon. Magmatic zircons equilibrated with mantle-derived magmas have average $\delta^{18} \mathrm{O}_{\mathrm{Zrc}}$ value of $+5.3 \pm 0.6 \%$ o

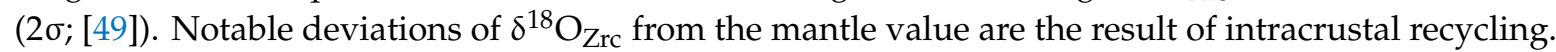
High- $\delta^{18} \mathrm{O}$ magmas $(+8 \%$ o to above $+10 \%$ ) reflect assimilation of supracrustal rocks that previously interacted with low temperature fluids [50], while low $\delta^{18} \mathrm{O}$ magmas (lower than ca. $+4 \%$ ) reflect assimilation of supracrustal rocks that previously interacted with meteoric water or seawater at high temperatures [46]. For the Nashwaak Granite, zircon in the biotite granite is in high temperature equilibrium with the coexisting quartz and crystallized in a closed system, thus hydrothermal alteration or assimilation of crustal rock can be ruled out during magma evolution. The homogeneous $\delta^{18} \mathrm{O}_{\mathrm{Zr}}$ within single grain or between different zircon rims, relatively homogeneous $\varepsilon_{\mathrm{Hf}}(t)$ (from -0.39 to -5.10) and "I-type" whole-rock geochemistry characteristics [8] indicate that the biotite granite might be dominantly derived by partially melting of meta-igneous rocks in the lower crust of Ganderia.

The two-mica granite has heterogeneous zircon cores $(+5.2 \%$ o to $+9.9 \%$ o), indicating multiple magma sources. Most $\delta^{18} \mathrm{O}_{\mathrm{Zrc}}$ of the zircon cores in the two-mica granite are the same as those of the biotite granite. Three cores with $\delta^{18} \mathrm{O}_{\mathrm{Zrc}}$ values of $+5.23 \%$ o to $+5.45 \%$ o represent a crustal mafic rock source instead of a juvenile mantle source because their ${ }^{206} \mathrm{~Pb} /{ }^{238} \mathrm{U}$ ages are older than $1.0 \mathrm{Ga}$. Zircon cores with $\delta^{18} \mathrm{O}_{\mathrm{Zrc}}$ of $+9.51 \%$ o to $+9.94 \%$ ore the result of assimilation of supracrustal rocks. This is supported by the feldspar $\mathrm{Pb}$ isotopic compositions of two-mica granite, which plot along or near the upper crust reference curve $\left({ }^{206} \mathrm{~Pb} /{ }^{204} \mathrm{~Pb}\right.$ vs. $\left.{ }^{207} \mathrm{~Pb} /{ }^{204} \mathrm{~Pb}\right)$ and on or near the orogene reference curve $\left({ }^{206} \mathrm{~Pb} /{ }^{204} \mathrm{~Pb}\right.$ vs. $\left.{ }^{208} \mathrm{~Pb} /{ }^{204} \mathrm{~Pb}\right)$ (see [51]). The biotite granite has $\varepsilon_{\mathrm{Hf}}(t)$ of -0.39 to -5.10 and older $\mathrm{T}_{\mathrm{DM} 2}$ ages of 1427 to $1724 \mathrm{Ma}$, while the two-mica granite has more negative $\varepsilon_{\mathrm{Hf}}(t)$ (as low as -11.7) and older $\mathrm{T}_{\mathrm{DM} 2}$ ages ( $\left.<2135 \mathrm{Ma}\right)$. This isotopic difference, caused by crustal assimilation, indicates that an "inverted" crustal structure (low $\varepsilon_{\mathrm{Nd}}(t)$ sedimentary rocks overlying more positive $\varepsilon_{\mathrm{Nd}}(t)$ crust), similar to that invoked by [4] for the Ganderia in Newfoundland.

\section{Conclusions}

This study indicates the in situ analysis of trace elements of zircon as well as oxygen isotope of both zircon and quartz is an effective way to distinguish crustal contamination from heterogeneity of magmatic source. Some Pridoli to Early Lochkovian granites in Ganderia, proposed to be formed by partial melting of heterogeneous source material (e.g., [52]), might not always be the case, such as the Nashwaak Granite investigated by this work. In situ Hf and O isotope measurements in zircon, the first such data reported for granites in New Brunswick's Central Plutonic Belt, record the detailed magmatic sources and petrogenetic processes of the Nashwaak Granite in the Miramichi Highlands. This granite is dominantly derived from partial melting of Ganderian lower crust and contamination from various supracrustal rocks. The unexposed basement has $\delta^{18} \mathrm{O}_{\mathrm{Zrc}}$ values between $+6.7 \%$ o and $+7.4 \%$, as reflected by inherited zircon cores in the biotite granite. The supracrustal rocks, including mafic rocks with $\delta^{18} \mathrm{O}_{\mathrm{Zrc}}$ of $+5.2 \%$ o to $+5.5 \%$ ond sedimentary materials with $\delta^{18} \mathrm{O}_{\mathrm{Zrc}}$ of $+9.5 \%$ o to $+9.9 \%$, were incorporated into a magma derived from the lower basement. Assimilation of those materials led to a decrease in the oxygen fugacity of the hybrid magmas, as indicated by trace element compositions of zircon.

Supplementary Materials: The following are available online at http://www.mdpi.com/2075-163X/10/7/614/s1, Table S1: Oxygen isotope of magmatic quartz from the Nashwaak Granitic suite, Table S2: Oxygen isotope of zircon from the Nashwaak Granitic suite, Table S3: Trace element composition of zircon in the Nashwaak Granite, Table S4: Hafnium isotope composition of zircon in the Nashwaak Granite. 
Author Contributions: Conceptualization, D.R.L. and W.Z.; methodology, D.R.L.; software, W.Z.; validation, D.R.L., W.Z., and K.G.T.; formal analysis, W.Z.; investigation, D.R.L.; resources, K.G.T.; data curation, W.Z.; writing-original draft preparation, W.Z.; writing—review and editing, W.Z.; visualization, W.Z.; supervision, D.R.L.; project administration, D.R.L.; funding acquisition, D.R.L. All authors have read and agreed to the published version of the manuscript.

Funding: This research was funded by the New Brunswick Department of Natural Resources (134404-46-01) and NSERC Discovery grant (217095).

Acknowledgments: Support by Charlie Morrissy and Justin Bernard during field work was greatly appreciated. Thanks to Geodex Minerals Ltd. for allowing access to their property and information. Edits from Reginald A. Wilson and Christopher J. Eastoe significantly improved this manuscript.

Conflicts of Interest: The authors declare no conflict of interest.

\section{References}

1. van Staal, C.R.; Barr, S.M. Lithospheric Architecture and Tectonic Evolution of the Canadian Appalachians and Associated Atlantic Margin; Special Paper; Geological Association of Canada: St. John's, NF, Canada, 2012; Volume 49, pp. 41-95.

2. van Staal, C.R.; Whalen, J.B.; Valverde-Vaquero, P.; Zagorevski, A.; Rogers, N. Pre-Carboniferous, episodic accretion-related, orogenesis along the Laurentian margin of the northern Appalachians. In Ancient Orogens and Modern Analogues; Special Publication; Murphy, J.B., Keppie, J.D., Hynes, A.J., Eds.; Geological Society: London, UK, 2009; Volume 327, pp. 271-316.

3. Whalen, J.B.; Jenner, G.A.; Longstaffe, F.J.; Hegner, E. Nature and evolution of the eastern margin of Iapetus: Geochemical and isotopic constraints from Siluro-Devonian granitoid plutons in the New Brunswick Appalachians. Can. J. Earth Sci. 1996, 33, 140-155. [CrossRef]

4. Kerr, A.; Jenner, G.A.; Fryer, B.J. Sm-Nd isotopic geochemistry of Precambrian to Paleozoic granitoid suites and the deep-crustal structure of the southeast margin of the Newfoundland Appalachians. Can. J. Earth Sci. 1995, 32, 224-245. [CrossRef]

5. Potter, J.; Longstaffe, F.J.; Barr, S.M. Regional ${ }^{18}$ O-depletion of Neoproterozoic igneous rocks from Avalonia, Cape Breton Island and southern New Brunswick, Canada. Geol. Soc. Am. Bull. 2008, 120, 347-367. [CrossRef]

6. Schofield, D.I.; D’Lemos, R.S. Granite petrogenesis in the Gander Zone, NE Newfoundland: Mixing of melts from multiple sources and the role of lithospheric delamination. Can. J. Earth Sci. 2000, 37, 535-547. [CrossRef]

7. van Staal, C.R. The Brunswick subduction complex in the Canadian Appalachians: Record of the Late Ordovician to Late Silurian collision between Laurentia and the Gander margin of Avalon. Tectonics 1994, 13, 946-962. [CrossRef]

8. Zhang, W.; Lentz, D.R.; Thorne, K.G.; Massawe, R.J.R. Late Silurian-Early Devonian slab break-off beneath the Canadian Appalachians: Insights from the Nashwaak Granite, west-central New Brunswick, Canada. Lithos 2020, 358-359, 105393. [CrossRef]

9. Dostal, J.; Keppie, J.D.; Wilson, R.A. Nd isotopic and trace element constraints on the source of Silurian-Devonian mafic lavas in the Chaleur Bay Synclinorium of New Brunswick (Canada): Tectonic implications. Tectonophysics 2016, 681, 364-375. [CrossRef]

10. Wilson, R.A.; Kamo, S.L. Geochronology and lithogeochemistry of granitoid rocks from the central part of the Central plutonic belt, New Brunswick, Canada: Implications for Sn-W-Mo exploration. Atl. Geol. 2016, 52, 125-167. [CrossRef]

11. Valley, J.W. Oxygen isotopes in zircon. Rev. Miner. Geochem. 2003, 53, 343-385. [CrossRef]

12. Page, F.Z.; Fu, B.; Kita, N.T.; Fournelle, J.; Spicuzza, M.J.; Schulze, D.J.; Viljoen, F.; Basei, M.S.; Valley, J.W. Zircons from kimberlite: New insights from oxygen isotopes, trace elements, and Ti in zircon thermometry. Geochim. Cosmochim. Acta 2007, 71, 3887-3903. [CrossRef]

13. Bowman, J.R.; Moser, D.E.; Valley, J.W.; Wooden, J.L.; Kita, N.T.; Mazdab, F.K. Zircon U-Pb isotope, $\delta^{18} \mathrm{O}$ and trace element response to $80 \mathrm{~m}$.y. of high-temperature metamorphism in the lower crust: Sluggish diffusion and new records of Archean craton formation. Am. J. Sci. 2011, 311, 719-772. [CrossRef]

14. Bindeman, I.N.; Valley, J.W. Low- $\delta{ }^{18} \mathrm{O}$ rhyolites from Yellowstone: Magmatic evolution based on analyses of zircons and individual phenocrysts. J. Petrol. 2001, 42, 1491-1517. [CrossRef] 
15. Monani, S.; Valley, J.W. Oxygen isotope ratios of zircons: Magma genesis of low $\delta^{18} \mathrm{O}$ granites from the British Tertiary Igneous Province, western Scotland. Earth Planet. Sci. Lett. 2001, 184, 377-392. [CrossRef]

16. King, E.M.; Valley, J.W.; Stockli, D.F.; Wright, J.E. Oxygen isotope trends of granitic magmatism in the Great Basin: Location of the Precambrian craton boundary as reflected in zircons. Geol. Soc. Am. Bull. 2004, 116, 451-462. [CrossRef]

17. Lee, R.G.; Dilles, J.H.; Tosdal, R.M.; Wooden, J.L.; Mazdab, F.K. Magmatic evolution of granodiorite intrusions at the El Salvador porphyry copper deposit, Chile, based on trace element composition and $\mathrm{U} / \mathrm{Pb}$ age of zircons. Econ. Geol. 2017, 112, 245-273. [CrossRef]

18. Zeh, A.; Stern, R.A.; Gerdes, A. The oldest zircons of Africa-their U-Pb-Hf-O isotope and trace element systematics and implications for Hadean to Archean crust-mantle evolution. Precambrian Res. 2014, 241, 203-230. [CrossRef]

19. Larson, T.E.; Sharp, Z.D. Interpreting prograde-growth histories of $\mathrm{Al}_{2} \mathrm{SiO}_{5}$ triple-point rocks using oxygen isotope thermometry: An example from the Truchas Mountains, USA. J. Metamorph. Geol. 2005, 23, 847-863. [CrossRef]

20. Longerich, H.P.; Jackson, S.E.; Günther, D. Inter-laboratory note. Laser ablation inductively coupled plasma mass spectrometric transient signal data acquisition and analyte concentration calculation. J. Anal. At. Spectrom. 1996, 11, 899-904. [CrossRef]

21. El-Bialy, M.Z.; Ali, K.A. Zircon trace element geochemical constraints on the evolution of the Ediacaran (600-614 Ma) post-collisional Dokhan Volcanics and Younger Granites of SE Sinai, NE Arabian-Nubian Shield. Chem. Geol. 2013, 360, 54-73. [CrossRef]

22. Li, X.H.; Long, W.G.; Li, Q.L.; Liu, Y.; Zheng, Y.F.; Yang, Y.H.; Chamberlain, K.R.; Wan, D.F.; Guo, G.H.; Wang, X.C.; et al. Penglai zircon megacrysts: A potential new working reference material for microbeam determination of Hf-O isotopes and U-Pb age. Geostand. Geoanal. Res. 2010, 34, 117-134. [CrossRef]

23. Jiang, H.; Li, W.Q.; Jiang, S.Y.; Wang, H.; Wei, X.P. Geochronological, geochemical and Sr-Nd-Hf isotopic constraints on the petrogenesis of Late Cretaceous A-type granites from the Sibumasu Block, Southern Myanmar, SE Asia. Lithos 2017, 268, 32-47. [CrossRef]

24. Blundy, J.; Wood, B. Prediction of crystal-melt partition coefficients from elastic moduli. Nature 1994, 372, 452-454. [CrossRef]

25. Sun, S.S.; McDonough, W.F. Chemical and isotopic systematics of oceanic basalts: Implications for mantle compositions and processes. In Magmatism in the Ocean Basins; Saunders, A.D., Norry, M.J., Eds.; Geological Society of London: London, UK, 1989; Special Publication; Volume 42, pp. 313-345.

26. Seyedolali, A.; Krinsley, D.H.; Boggs, S.; O’Hara, P.F.; Dypvik, H.; Goles, G.G. Provenance interpretation of quartz by scanning electron microscope-cathodoluminescence fabric analysis. Geology 1997, 25, 787-790. [CrossRef]

27. Miller, J.S.; Wooden, J.L. Residence, resorption and recycling of zircons in Devils Kitchen Rhyolite, Coso volcanic field, California. J. Petrol. 2004, 45, 2155-2170. [CrossRef]

28. Watson, E.B.; Wark, D.A.; Thomas, J.B. Crystallization thermometers for zircon and rutile. Contrib. Mineral. Petrol. 2006, 151, 413-433. [CrossRef]

29. Wooden, J.L.; Mazdab, F.K.; Barth, A.P.; Miller, C.F.; Lowery, L.E. Temperatures (Ti) and compositional characteristics of zircon: Early observations using high mass resolution on the USGS Stanford SHRIMPRG. Geochim. Cosmochim. Acta 2006, 70, A707. [CrossRef]

30. Deering, C.D.; Keller, B.; Schoene, B.; Bachmann, O.; Beane, R.; Ovtcharova, M. Zircon record of the plutonic-volcanic connection and protracted rhyolite melt evolution. Geology 2016, 44, 267-270. [CrossRef]

31. Ferry, J.M.; Watson, E.B. New thermodynamic models and revised calibrations for the Ti-in-zircon and Zr-in-rutile thermometers. Contrib. Mineral. Petrol. 2007, 154, 429-437. [CrossRef]

32. Watson, E.B.; Harrison, T.M. Zircon thermometer reveals minimum melting conditions on earliest Earth. Science 2005, 308, 841-844. [CrossRef]

33. Large, S.J.; Quadt, A.V.; Wotzlaw, J.F.; Guillong, M.; Heinrich, C.A. Magma evolution leading to porphyry Au-Cu mineralization at the Ok Tedi deposit, Papua New Guinea: Trace element geochemistry and high-precision geochronology of igneous zircon. Econ. Geol. 2018, 113, 39-61. [CrossRef]

34. Shen, P.; Hattori, K.; Pan, H.; Jackson, S.; Seitmuratova, E. Oxidation condition and metal fertility of granitic magmas: Zircon trace-element data from porphyry $\mathrm{Cu}$ deposits in the Central Asian Orogenic Belt. Econ. Geol. 2015, 110, 1861-1878. [CrossRef] 
35. Ballard, J.R.; Palin, J.M.; Campbell, I.H. Relative oxidation states of magmas inferred from Ce(IV)/Ce(III) in zircon: Application to porphyry copper deposits of northern Chile. Contrib. Mineral. Petrol. 2002, 144, 347-364. [CrossRef]

36. Trail, D.; Watson, E.B.; Tailby, N.D. Ce and Eu anomalies in zircon as proxies for the oxidation state of magmas. Geochim. Cosmochim. Acta 2012, 97, 70-87. [CrossRef]

37. Burgisser, A.; Scaillet, B. Redox evolution of a degassing magma rising to the surface. Nature 2007, 445, 194. [CrossRef] [PubMed]

38. Dilles, J.H.; Kent, A.J.; Wooden, J.L.; Tosdal, R.M.; Koleszar, A.; Lee, R.G.; Farmer, L.P. Zircon compositional evidence for sulfur-degassing from ore-forming arc magmas. Econ. Geol. 2015, 110, 241-251. [CrossRef]

39. Trail, D.; Bindeman, I.N.; Watson, E.B.; Schmitt, A.K. Experimental calibration of oxygen isotope fractionation between quartz and zircon. Geochim. Cosmochim. Acta 2009, 73, 7110-7126. [CrossRef]

40. Valley, J.W.; Bindeman, I.N.; Peck, W.H. Empirical calibration of oxygen isotope fractionation in zircon. Geochim. Cosmochim. Acta 2003, 67, 3257-3266. [CrossRef]

41. King, E.M.; Barrie, C.T.; Valley, J.W. Hydrothermal alteration of oxygen isotope ratios in quartz phenocrysts, Kidd Creek mine, Ontario: Magmatic values are preserved in zircon. Geology 1997, 25, 1079-1082. [CrossRef]

42. King, E.M.; Valley, J.W.; Davis, D.W. Oxygen isotope evolution of volcanic rocks at the Sturgeon Lake volcanic complex, Ontario. Can. J. Earth Sci. 2000, 37, 39-50. [CrossRef]

43. Appleby, S.K.; Graham, C.M.; Gillespie, M.R.; Hinton, R.W.; Oliver, G.J.H. EIMF. A cryptic record of magma mixing in diorites revealed by high-precision SIMS oxygen isotope analysis of zircons. Earth Planet. Sci. Lett. 2008, 269, 105-117. [CrossRef]

44. Appleby, S.K.; Gillespie, M.R.; Graham, C.M.; Hinton, R.W.; Oliver, G.J.H.; Kelly, N.M. EIMF. Do S-type granites commonly sample infracrustal sources? New results from an integrated $\mathrm{O}, \mathrm{U}-\mathrm{Pb}$ and $\mathrm{Hf}$ isotope study of zircon. Contrib. Mineral. Petrol. 2010, 160, 115-132. [CrossRef]

45. Gagnevin, D.; Daly, J.S.; Horstwood, M.S.A.; Whitehouse, M.J. In-situ zircon U-Pb, oxygen and hafnium isotopic evidence for magma mixing and mantle metasomatism in the Tuscan Magmatic Province, Italy. Earth Planet. Sci. Lett. 2011, 305, 45-56. [CrossRef]

46. Bindeman, I.N. Oxygen isotopes in mantles and crustal magmas as revealed by single crystal analysis. Rev. Mineral. Geochem. 2008, 69, 445-478. [CrossRef]

47. Miles, A.; Graham, C.; Hawkesworth, C.; Gillespie, M.; Dhuime, B.; Hinton, A.R. Using zircon isotope compositions to constrain crustal structure and pluton evolution: The Iapetus Suture Zone granites in Northern Britain. J. Petrol. 2014, 55, 181-207. [CrossRef]

48. King, E.M.; Valley, J.W. The source, magmatic contamination, and alteration of the Idaho batholith. Contrib. Mineral. Petrol. 2001, 142, 72-88. [CrossRef]

49. Eiler, J.M. Oxygen isotope variations of basaltic lavas and upper mantle rocks. Rev. Mineral. Geochem. 2001, 43, 319-364. [CrossRef]

50. King, E.M.; Trzaskus, A.P.; Valley, J.W. Oxygen isotope evidence for magmatic variability and multiple alteration events in the Proterozoic St. Francois Mountains, Missouri. Precambrian Res. 2008, 165, 49-60. [CrossRef]

51. Ayuso, R.A.; Bevier, M.L. Regional differences in lead isotopic compositions of feldspars from plutonic rocks of the northern Appalachian Mountains, U.S.A. and Canada: A geochemical method of terrane correlation. Tectonophysics 1991, 10, 191-212.

52. Whalen, J.B.; McNicoll, V.J.; van Staal, C.R.; Lissenberg, C.J.; Longstaffe, F.J.; Jenner, G.A.; van Breeman, O. Spatial, temporal and geochemical characteristics of Silurian collision-zone magmatism, Newfoundland Appalachians: An example of a rapidly evolving magmatic system related to slab break-off. Lithos 2006, 89, 377-404. [CrossRef]

(C) 2020 by the authors. Licensee MDPI, Basel, Switzerland. This article is an open access article distributed under the terms and conditions of the Creative Commons Attribution (CC BY) license (http://creativecommons.org/licenses/by/4.0/). 